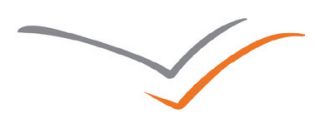

STUDIA HISTORIAE OECONOMICAE

UAM Vol. $31 \quad$ Poznań 2013

\title{
VERSITA
}

Jacek Kubera (Adam Mickiewicz University, Poznań)

\section{SUBURBS, IMMIGRANTS AND ETHNICITY. AUTOBIOGRAPHICAL NOVELS OF ALGERIAN IMMIGRANTS IN FRANCE AS AN ATTEMPT OF EMANCIPATION FROM ETHNIC DISCRIMINATION DISCOURSE}

The article applies to three autobiographical novels written in the 1980s and 1990s by citizens of France, second generation Algerian immigrants. The authors of these novels widely relate to their own experience of life in the suburbs of French cities. The protagonists are young people who on the one hand feel French and demand acceptance, and on the other experience acts of discrimination. Moreover, their relationship to traditional Algerian culture is also ambivalent. The place with which they identify themselves is not France, in spite of the citizenship, nor Algeria, in spite of the origin, but their own district, which is a place where they live their everyday life. The author of the article analyzes the chosen novels through the perspective of the republican model of integration which excludes recognition of ethnic origin of the citizens. The article, referring to M. Foucault's theory of heterotopia, argues that although the novels in question sensitize French readers to the various social questions, they, paradoxically, support the typical thinking of the republican model.

Keywords: suburbs, immigrants, republic model of integration, Algerians, minor literature.

doi: 10.2478/sho-2013-0007

\section{ALGERIANS AND OTHER IMMIGRANTS IN THE DOMINANT DISCOURSE IN FRANCE}

Depending on the policy of a given country, the otherness of immigrants may be treated as a chance or as a threat for the development. Australia and Canada are examples of countries, which wrote their exemplar multiculturalism - understood mainly as resignation from the dominance of only one cultural and linguistic model - in their constitutions, 
perceiving it as one of the most important values ${ }^{1}$. On the other end of the continuum one can place the Great Britain of the 70s and all countries, which - similarly to the contemporary France - accepted the republican model of integration of immigrants ${ }^{2}$. This model, having its roots in the Revolution of 1789 that unified the French country, significantly stresses the equality of citizens with respect to the law, giving them the same privileges, but also duties - regardless of their regional or national provenance, or their religion. That is why it is thought that the French Republic did not assimilate ethnic groups as such in any period of its existence, but as "free and equal" individuals ${ }^{3}$. This is as well the reason why examples of racial segregation in cities are still unnoticed by the government, as the universalist French tradition excludes thinking about social or spatial organisation by means of ethnic diversity ${ }^{4}$.

Meanwhile, the riots in the suburbs of Paris and other major French cities in 2005 showed that the problem of social exclusion and discrimination of many young people in France is correlated with their ethnic origin $^{5}$. The unemployment of children whose parents arrived to France just after World War II during a period of industrial development (les Trente Glorieuses), has been a great problem since the seventies. French authorities have considered them in terms different than the ethnic ones. The media and society more generally often talk about "difficult districts", the

${ }^{1}$ E. Możejko, Wielka szansa czy iluzja: wielokulturowość w dobie ponowoczesności, [in:] W. Kalaga (ed.), Dylematy wielokulturowości, Kraków 2004, pp. 141-61; J.Smolicz, Globalizacja, suwerenność państwowa i wielokulturowość, [in:] A. Borowiak, P. Szarota, (ed.), Tolerancja i wielokulturowość. Wyzwania XXI wieku, Warszawa, 2004, pp. 56-69.

2 P. Szarota, Brytyjska droga do wielokulturowości, [in:] A. Borowiak, P. Szarota (eds.), op. cit., pp. 80-93.

${ }^{3} \mathrm{G}$. Felouzis, De l'école à la ville: comment se forment les 'collèges ghettos'? À partir d'une enquête statistique dans l'Académie de Bordeaux, Informations socials, Nr 125/2005, p. 39.

${ }^{4}$ R. Epstein, T. Kirszbaum, L'enjeu de la mixité sociale dans les politiques urbaines, Regards sur l'actualité - Compétitivité de la France, Nr 292/2003, p. 4.

${ }^{5}$ About the racial and ethnic discrimination on the education and labor market in France see G. Vinsonneau, L'identité des jeunes en situation inégalitaire. Le cas des Maghrébins en France, Paris 1996; É. Perrin, Jeunes Maghrébins de France. La place refusée, Paris 2008; F. Aubert, M. Tripier, F. Vourc'h, (ed), Jeunes de l'immigration de l'école à l'emploi, ParisMontréal 1997; M. Rebzani, A. Durand-Delvigne, Politiques d'insertion sociale et professionnelle et discriminations des jeunes d'origine non européenne, L'orientation scolaire et professionnelle, Nr 32(4)/2003; A. Frickey, J. Murdoch, J-L. Primon, Les jeunes issus de l'immigration. De l'enseignement supérieur au marché du travail, Céreq, Nr 205/2004; R. Silberman, I. Fournier, Les secondes générations sur le marché du travail en France: une pénalité ethnique ancrée dans le temps. Contribution à la théorie de l'assimilation segmentée, Revue française de sociologie, Nr 47(2)/ 2006. 
problem of the suburbs and the problem of "the youth from the housing estates" which builds a general stereotype of "the dangerous youth from the suburbs" 6 .

The presence of immigrants in the French society has two dimensions in this context. On the one hand, the government, by creating special programs helping the outskirts of the cities, does not take into consideration the specificity of these places. They try not to bring up the fact that the people who live there are largely immigrants coming from the former French colonies and from other parts of the world. The cultural otherness of Algerians and other immigrants is concealed in this case, as if purposefully unnoticed ${ }^{7}$. On the other hand, from the end of the seventies till today, French public opinion about the suburbs has been very negative, and the outskirts are associated with the stereotype of an unintegrated Muslim society, undermining the basic values of the Republic, among them the rule of laity of the French nation. Since the beginning of the eighties, ethnic minorities are - wrongly - identified with dangerous people endangering the society in general and, especially, the middle classes, which, though living in difficult conditions, are brought up from one generation to another in the obeying of the letter of the law $^{8}$.

It is worth remembering that the outskirts were not always perceived as a source of problems. Especially in the fifties (in the first period of the thirty years of intense economic growth) the authorities perceived them as a chance to modernize a country rent by war and too agricultural. "Modernization through urban development" meant creating huge estates on the boundaries of cities, offering spacious, comfortable flats, with totally new sanitary standards, which finally seemed to be a remedy to the problems connected with spatial, social and political problems connected with the growth of the city. The flats (les habitations à loyer modéré, les HLM) were perceived as a very egalitarian solution, intended for all the workers - "from qualified workers to engineers", as one contemporary leaflet said".

${ }^{6}$ C. Attias-Donfut, F-Ch. Wolff, Le destin des enfants d'immigrés. Un désenchaînement des générations, Paris 2009, p. 270; M. Kokoreff, Du stigmate au ghetto. De la difficulté à nommer les quartiers, Informations sociales, Nr 141/2007, p. 91.

${ }^{7}$ Ibid, pp. 81-3; see: F. Durpaire, France blanche, colère noire, Paris 2006; J-B. Onana, Sois nègre et tais-toi!, Paris 2007.

${ }^{8} \mathrm{~J}$. Donzelot, Quand la ville se défait. Quelle politique face à la crise des banlieues?, Paris 2006, p. 17.

${ }^{9}$ Ibid, pp. 45-6. 
The creation of a negative and simplified view of the outskirts was influenced by the media showing bipolar vision of social conflicts in France. In this falsified, simplified coverage, there were on the one hand immigrants, workers performing simple jobs, the unemployed on welfare, people in danger of contact with the criminal world, religious fanatics, and people occupying suburban or downgraded areas of the cities. On the other, there were indigenous, well-paid Frenchmen, who followed Republican rule on the separation of the country from religion, occupying the central districts of the city, the ones perceived mainly as bourgeoisie or the socalled "beautiful districts" [les beaux quartiers] ${ }^{10}$. Ethnic dissimilarity in this dimension is connected with everything that does not suit the model of a citizen, becoming a core for the distinction of the groups that should be deprived of the privilege of the citizenship or do not deserve to be called citizens. The suburbs (fr. banlieue) again mean the same as it meant in the Middle Ages when this word first appeared: the place of exile, the area of being banished outside the boundaries of the city ${ }^{11}$. While in the past banishment resulted from the decisions reached in accordance with the then law, today it is forced by the lack of an appropriate policy of the country that would level the social and economic inequalities connected with the immigrant's past and ethnic background. The image of the residents of the suburbs, shaped in the beginning of the eighties, in the dominant discourse is reduced either to a victim of discrimination or to dangerous bands of youths ${ }^{12}$.

Talking about the predominant discourse in France, one has to stress, following M. Foucault ${ }^{13}$, that the discourse has to be perceived as violence imposed on realistically existing objects (here: Algerians and other immigrants) and as a practice imposed on these objects. The non-subjective, real aspect of violence having its roots in language was also noticed by P. Bourdieu ${ }^{14}$.

In addition, it is worth noticing one more characteristic of every discourse - both the dominant ones and the others trying to contrast with it.

\footnotetext{
10 Ibid, p. 22.

11 J. Rey-Debove, A. Rey, Le Nouveau Petit Robert. Dictionnaire alphabétique et analogique de la langue fraçaise, Paris 2007, p. 218.

12 S. Beaud, M. Pialoux, La 'racaille' et les 'vrais jeunes'. Critique d'une vision binaire du monde des cites, Liens socio, $\mathrm{Nr}$ 2/2005.

${ }^{13}$ M. Foucault, L'ordre du discours. Leçon inaugurale au Collège de France prononcée le 2 décembre 1970, Paris 1971, p. 55.

${ }^{14}$ P. Bourdieu, Langage et pouvoir symbolique, Paris 2001, pp. 59-60.
} 
They all cannot be judged, regardless of the norms established by the society. Foucault claims that in every condition the production of the discourse is simultaneously controlled, selected, organised and popularised by various kinds of procedures aimed at combining seemingly contradictory ideas and coming to terms with the interests of the authorities and the communities threatening $\mathrm{it}^{15}$. Three basic procedures set by the French philosopher may be treated as rules not only restricting the debate of the politicians in the media, but also the everyday discourse of ordinary conversations. The procedures, according to Foucault, are prohibition (we are not allowed to say everything; what we can say depends on the circumstances; not everyone can talk nonsense), contrasting common sense with madness, and contrasting the truth with falsehoods (the last two procedures refer to common knowledge) ${ }^{16}$.

In accordance to the term used by Foucault ${ }^{17}$, we can assume that Algerians, similarly to other immigrants in France, are distinguished by their origin and are perceived in the dominant discourse as uncivilized barbarians. Ethnic, lingual and religious dissimilarity of Algerians is connected with the characteristics of non-citizens, people living in the same country but representing values foreign to the dominant community of "we". Besides, following what Foucault says about the figure of a barbarian, the knowledge of the Algerians resulting from their everyday life experience is perceived as local, disqualified, illegitimate and non-scholastic. Contrary to the figure of a wild man, who is untamed as long as they are not connected by any social relationship, a barbarian cannot be characterised in a different way than their attitude towards the civilisation outside of which they are; there is no barbarian if there is not any element of civilisation they do not share. In addition, differently than a wild man, who is always good, a barbarian cannot be perceived as bad, arrogant and inhuman, as they themselves are neither a human of some other civilisation, with whom one could for example trade, nor a savage, uncorrupted by any sort of civilisation ${ }^{18}$.

\footnotetext{
${ }^{15}$ Foucault, L'ordre du discours, pp. 10-11.

16 Ibid, pp. 11 and 16.

17 Foucault, Michel, "Il faut défendre la société": cours au Collège de France, 1975-1976, Gallimard \& Éditions du Seuil, Paris, 1997, p. 174.

18 Ibid, p. 175.
} 


\section{AUTOBIOGRAPHICAL NOVELS OF ALGERIAN IMMIGRANTS AS AN EXAMPLE OF HETEROTOPIAS}

The literature I would like to present at this point of the article, should be considered as an example of cultural activity of members of the Algerian minority, the aim of which was to present their own view on the outskirts of French cities.

These are over twenty autobiographical novels written in the eighties and nineties, the authors of which are children of Algerian immigrants, so people already brought up in France, going to French schools, having French nationality and highly rooted in French culture ${ }^{19}$. The literature belonging to this genre is very often preceded with an adjective beur that refers to young Maghrebians born in France or called "Maghrebian literature of French language", which highlights the double cultural and sociolinguistic identity of the authors of these books ${ }^{20}$. The conclusions presented here I will base mainly on the reading of three novels: Tea in the Harem by Mehdi Charef from 1983, a book which started the flow of beur literature 21, Béni or private paradise by Azouz Begag from $1989^{22}$ and Cities' Ash by Mohand Nafaa Mounsi from $1993^{23}$. Each of these novels was published in a renowned publishing house, which can be interpreted as an attempt at legitimization of this kind of literature and also an attempt of these authors to become a part of French literature in general. Similarly to the whole beur stream of literature from the eighties and nineties, these novels are mainly devoted to the life on the outskirts. These literary works are based on the personal experiences of the particular authors, but they are also treated as an autobiography of the whole generation of Algerian children, who, in the period of les Trente Glorieuses, settled in France ${ }^{24}$. They present similar

${ }^{19}$ C. Camilleri, Positionnement identitaire chez l'adolescent maghrébin en France, [in:] N. Kridis (ed.), Adolescence et identité, Hommes et perspectives, Marseille 1990; J. Simon (ed), L'immigration algérienne en France. De 1962 à nos jours, Paris 2002; J-F. Bruneaud, Chroniques de l'éthnicité quotidienne chez les Maghrébins français, Paris 2005.

${ }^{20}$ F. Desplanques, Quand les Beurs prennent la plume, Revue européenne de migrations internationales, Nr 3/1991, p. 140.

${ }^{21}$ M. Charef, Le thé au harem d'Archi Ahmed, Paris 1983. In the French title a play of words is highlighted: meaning connection of the name of ancient scholar, Archimedes with Arabic name, Ahmed.

22 A. Begag, Béni ou le paradis privé, Paris 1989.

${ }^{23}$ M.N. Mounsi, La Cendre des villes, Paris 1993.

${ }^{24}$ H. Sebhkhi, Une littérature "naturelle": le cas de la littérature 'beur', Itinéraires et contacts de cultures, $\mathrm{Nr} 27 / 1999$. 
trajectories through which probably the majority of children of Maghreb immigrants in the eighties underwent similar cycles or experiences: coming to the big city with parents, living their childhood in shantytowns, moving to a block of flats in the suburbs, failing at school, experiencing the first acts of racial discrimination, sexual initiations, lack of understanding on the part of the police, identification of young Algerians with criminals by native Frenchmen, parents' attempts to provide the best future for their children, despite their own difficult working conditions, contacts of the young with criminal world, a series of failures in the labor market, and feeling an overwhelming sense of injustice ${ }^{25}$.

The critics perceived beur literature as a voice of young Algerians in the discussion on the topic of French suburbs, and as a voice opposing the media view on the outskirts which dominated the public discourse in France. From this point of view, the novels of Charef, Begag and Mounsi can be an example of the minor literature, meaning one that presents topics important for minorities (national, ethnic, regional, religious, sexual and other), whichare usually overlooked or unnoticed by the traditional canonical literature of the dominant culture. Franz Kafka introduced the phrase "minor literature" 26: "what is in the bosom of great literatures is played down and is the necessary basement of the whole building, but here happens in the full light" ${ }^{27}$. It is worth noticing that according to G. Deleuze and F. Guattari the word "minor" does not mean anything negative here; it just refers to the "literature, which is written in the language of the majority by the minority" 28 . They perceive the literary creation as an act of opposition to the norms imposed by language and discursive practices extending its hegemony not only over the linguistic sphere but also in every other sphere of social, cultural and political life of a given country. According to G. Sibertin-Blanc, one of the functions carried out by this

${ }^{25}$ F. Desplanques, Quand les Beurs, p. 141.

${ }^{26}$ Kafka used this term with respect to the placement of the Jewish minority in the Czech Republic in the Austrian-Hungarian Empire, and especially in Prague where in the beginning of the twentieth century coexisted German language - a language of administration, trade, culture, universities and Czech - a language of the biggest part of the population, and Yiddish - used by the majority of German-speaking Jews, which was a language despised both by the Czechs and Germans; see G. Sibertin-Blanc, Deleuze et les minorités: quelle 'politique'?', Cités, Nr 40/2009, p. 40.

27 Cited after L. Gauvin, Autour du concept de littérature mineure. Variations sur un thème majeur, [in:] J-P. Bertrand, L. Gauvin, (eds.), Littératures mineures en langue majeure, Bruxelles 2003, p. 25.

${ }^{28}$ Ibid, p. 20. 
kind of literature is the creation of a new way of expression on topics important for the minority, and also promotion of other kinds of collective awareness, other sensibilities, and, in consequence, creation from a given minority a more rebellious community, freed from the imposed vision of the world, and able to protect its interests ${ }^{29}$.

In this way the literature written by young Algerians in the eighties and nineties is an example of heterotopias, meaning a cultural enclave in which a different way of perceiving the world or - even more - in which the world, with different rules of understanding and interpretation, can exist. Following M. Foucault, it is believed that heterotopias are places of otherness and to experience otherness. On the one hand they are not a margin, but a qualitatively different space impinging on the reality enclosed in its frames; on the other hand, they do not exist without the thing it remonstrates ${ }^{30}$.

What mainly distinguishes the three chosen novels from the dominant discourse is the placing of the identity of young Algerians in a district in which they live, not on their separate ethnic background. Below I present a few arguments showing that the suburbs (or a specific district or housing estate) and not ethnic dissimilarity establishes the identity of young Algerians. The corroboration of this theory seems to be quite important as it would confirm the demand of Algerians - by means of the literature written by them; they expect a treatment equal with other citizens of France and the same chances of social promotion as native Frenchmen.

In proving the thesis about building the identity of young Algerians based on the area occupied by them, one has to start with the statement that the novels of Begag, Charef and Mounsi are full of examples proving social inequalities having their roots in spatial segregation between native Frenchmen and immigrants as well as racially discriminatory acts. Presenting the histories of the disfavoured protagonists in a photographical, even naturalistic way, they in fact object to the discourse of power, according to which the citizens of France are treated by the country in the same way, regardless of their origin or religion. In this case we should agree with J. Fiske, who writes that realism is not a case of being faithful to the empiric reality, but rather it is a case of discursive conventions, through and for which a particular sense of reality is constructed. Realism,

${ }^{29}$ G. Sibertin-Blanc, Deleuze et les minorities, pp. 41-3.

${ }^{30}$ M. Brzozowska-Brywczyńska, Opowieści niezwykłe Elektronicznego Bajarza. Zapiski na marginesach, [in:] B. Darska (ed.), Kultura wobec odmienności. Tom 1: Dyskursy: Film/Telewizja, Warszawa 2009, p. 200. 
following M. Brzozowska-Brywczyńska's comment on Fiske, though it creates a sense of transparency, which bears features of objectiveness under the mask of impartial universalism, hides its particular, historical-cultural construction ${ }^{31}$.

The importance of the suburbs in the life of young Algerians as shown in the novels is based on the fact that it is the district where they spend the majority of time. If they happen to be in the centre of the cities, they are rather on the streets, wandering aimlessly or by means of public transport, travelling to the outskirts and back. However, these are not places in an anthropological sense, as they are very often deprived of any identity, relation or historicity ${ }^{32}$. Whereas the buildings of public institutions having their place in the city centre, such as the mayoralty, the social assistance house, as well as schools and police stations, are foreign to them, belonging to different social groups. First, it is here where Algerians very often sense that their ethnic dissimilarity is perceived by the rest of French society negatively, identified with poverty or criminal behaviour ${ }^{33}$. Secondly, in these places in the city centre they become convinced they have lower competence when it comes to the knowledge of French culture than ordinary Frenchmen, and their cultural standards and norms differ from the cultural "standard" of the Republic (which is only a false conviction contrary to the facts ${ }^{34}$ ). It is different in their district where they feel at home: they know social codes and share similar hierarchy of values with occupants similar to them ${ }^{35}$. Because other spaces are dominated by culture, which is not their own, the district plays, on the one hand, the role of a safe enclave, and on the other, a separated place, enclosing the majority of their social relationships and, in consequence, preventing them from contact with other groups ${ }^{36}$.

In the analysed novels, the unaesthetic, ugly view of the blocks of flats confirms in a way the fact that it is a space for strangers. Almost on every wall there is graffiti and vulgar inscriptions. The novels very often talk about odours in the flats, on the staircases, in the basements, and in under-

${ }^{31}$ Ibid, p. 195.

${ }^{32}$ M. Augé, Non-Lieux. Introduction à une anthropologie de la surmodernité, Paris 1992, p. 62 .

33 See C. Attias-Donfut, F-Ch. Wolff, Le destin des enfants d'immigrés, p. 270.

34 See M. Hatzfeld, La culture des cités. Une énergie positive, Paris 2006; M. Hatzfeld, Petit traité de la banlieue, Paris 2004.

35 Ibid.

${ }^{36}$ F. Dubet, Sociologie de l'expérience, Paris 1994, pp. 186-200. 
ground passages. Substances such as drugs, cigarettes, and cigars are typically associated with these places. In comparison to other parts of the city, the material that seems to characterise the suburbs best is concrete. It is the building material for blocks of flats that are compared to "the concrete mountains" ${ }^{\prime 3}$, and its smell that cannot be eradicated in any way, dominating all the parts of the district. What is more, people living in this district gradually become similar to this material, losing their human traits: "here they grow and more and more resemble concrete, dry and cold. They are dry and cold, raw, seemingly indestructible, however, there are also cracks in concrete. One cannot eradicate this concrete. It is ubiquitous, in gestures, in voice, in tongue, in eyes (...). Even in Peru it will accompany anyone who was born in concrete, like a shadow" 38 .

The suburbs are in the centre of the identity of young Algerians in France not only because it is the place where the most important scenes from their life occur. It is also the space surrounding them every day; in fact, it is the only place with which they can identify. While Algeria is still homeland for the immigrants of the first generation ${ }^{39}$, Algerians belonging to the second generation cannot strictly say whether they are connected more with the land of their predecessors or France. Neither country is their own. An example of such thinking is Madjid, a protagonist of Charef's novel, who is convinced for a long time of being neither an Arab nor a Frenchman ${ }^{40}$. He is the son of immigrants, lost between two cultures, two histories, two languages, two colours of skin, neither black, nor white. He has to invent his own roots, his connections; he has to fabricate them".

Not only do the young Algerians have sometimes low competence when it comes to the knowledge of French culture but also they do not feel connected with the culture of their parents, which is very often highlighted by various generational conflicts. In Mounsi's book, a pair of the main protagonists named Nadjem and Marina do not want to be different from the French and, contrary to their parents, who are constantly thinking about returning to Algeria, they know that their stay in France is not "just for a moment". Begag, on the other hand, shows this willingness to be the same as others in the society by his unsuccessful attempts of persuading the family of a boy named Béni to celebrate Christian cel-

\footnotetext{
${ }^{37}$ M.N. Mounsi, La Cendre, p. 41.

${ }^{38}$ M. Charef, Le thé, pp. 62-62.

${ }^{39}$ N. Beau, Paris, capitale arabe, Paris 1995, p. 55.

${ }^{40}$ M. Charef, Le thé, p. 17.
} 
ebrations, which the boy associates with joyful atmosphere, a decorated Christmas tree and presents. "We could pretend to be similar, it does not cost much but would give a lot of joy for us, children" - persuades Béni ${ }^{41}$. Besides, a lot of space is devoted to the attitude towards the language. The youth, although they can speak Arabic, they use it only in contacts with parents, only in some unique circumstances. In their everyday conversations with friends from the district, they use French, though in a familiar, vulgar or even argotic way. For the first generation of immigrants, on the other hand, the French language is connected with the language of dominance; it is the language of the former colonizer, and thus they feel excluded from the spheres of family and cultural life; they use it only in more formal circumstances, for example at work or in contacts with people who do not know Arabic.

It is clearly visible that, although young immigrants know they are not accepted by Frenchmen, they do not perceive themselves as Algerians, and the culture, which in fact is theirss, is the culture of street, created during contacts with other immigrants and also with French, with whom they share the fate of poor citizens of the suburbs with no chance of social promotion.

\section{HETEROTOPIAS WHICH DOES NOT EXIST WITHOUT THE THING IT DEMONSTRATES}

Novels written by Algerians object to thoughtlessly accepted judgements treating the first and second generation as a whole. From the books of Begag, Charef and Mounsi it is clear that, contrary to popular belief, young Algerians should be treated as an important, however, very frustrated, part of French society.

They take up the attitude of being differentiated from their parents and in contacts with French society - loudly and sometimes brutally - they demand equal treatment, opposing visible and hidden manifestations of discrimination. While the members of the first generation do not want to become full members of French society and in reality, by means of numerous contacts with the community of immigrants from Maghreb, they build a society within a society, members of the second generation do not refrain

${ }^{41}$ A. Begag, Béni ou le paradis privé, p. 19. 
from a dialogue with other social and ethnic groups in France, trying not to restrict themselves to just one, clearly defined ethnic group ${ }^{42}$.

That is why, contrary to what media claim, it is the first group of immigrants who should be perceived as the disintegrated one, creating a separate society, while their children are just an ill-integrated society (or integrated in a wrong way in the eyes of the authorities), and as a society integrated with people of lower ranks of French society, occupying the lowest ranks: with the poor, undereducated, representing something different than the dominant bourgeois values. The message of the beur literature is clear: 1) the problem of the suburbs is not ethnic, but first of all social 2) although strongly stigmatised by the dominant discourse, the suburbs are the places where one could feel a sense of belonging and social solidarity ${ }^{43}$.

This literature highlights that for young Algerians, the basic building material for identity are the actual suburbs themselves and not necessarily the family, the Muslim religion or their ethnic background. This proves that the problem of "difficult districts" in France is a social, not an ethnic problem ${ }^{44}$. A dissimilar outlook very often is the cause of being discriminated against, young Algerians demand such a treatment that would not mind this difference. Paradoxically, Algerian novels, which, as a minor literature, should object to the dominant discourse (showing lack of justification for the stereotypes, and fight with examples of discrimination), also prove a lot of statements proposed by the followers of the Republican model of integration.

In fact the beur literature can be treated as a safety valve necessary for the correct functioning of the system: young Algerians in France try to eradicate their ethnic otherness, and they demand a treatment that would ignore their descent. Just as in the Republican model, the ethnic difference is not affirmed; it is not a potential source of enriching the social relationships, but an obstacle in the building of the society of equal (in Republican understanding: identical) citizens.

Basing individual and collective identity on the sphere of one's own district shows that in the case of young immigrants, the Republican model of integration has definitely ousted the category of ethnicity out of the

42 See B. Stora, Ils venaient d'Algérie. L'immigration algérienne en France (1912-1992), Paris 1992, p. 436.

43 See M. Hatzfeld, La culture des cites, op. cit.

44 See S. Beaud, M. Pialoux, La 'racaille' et les 'vrais jeunes'; W. Hładkiewicz, Obcy w wielokulturowej Europie - casus francuski, [in:] D. Angutek (ed.), "Obcy" w przestrzeni kulturowej wspótczesnej Europy, Zielona Góra 2009. 
Algerians' thinking about themselves. However, this "success" of the Republic has its pros and cons. Unwillingness to being perceived in an ethnic perspective not only blocks identification with Algeria (which is the thing integralists probably want) but also with the French nation (which should be treated as a defeat of the Republican model). Autobiographical novels written by young Algerians not only cease to free the society discussed from the stereotypical picture of the dangerous citizen of the suburbs, but they even intensify this negative picture, showing the protagonists of these books as incongruous with both Algerians and Frenchmen, as strange, detached people, closed in the cage of their own district. Surely, the very fact that such literature exists and thus enriches the literary field with new topics and problems, is very important, but discussing it only with respect to the emancipation categories, seems to be, unfortunately, a serious abuse.

Jacek Kubera - graduate of sociology and French studies, Ph.D. student in the Institute of Sociology at the Adam Mickiewicz University in Poznan, an intern at the University Paris 7 Diderot and the École des Hautes Études en Sciences Sociales in Paris. His scientific interests focus on migration, identity and the problems of urban sociology. 